\title{
PRODUKSI CITRA POLISI DALAM FILM : SEBUAH UPAYA SAKRALISASI (Analisis Genre Pemenang Police Movie Festival 2017-2019)
}

\author{
Muria Endah Sokowati ${ }^{1}$, Frizki Yulianti Nurnisya ${ }^{2}$ \\ 1'muriaendah@umy.ac.id, ${ }^{2}$ frizkinurnisya@umy.ac.id \\ Universitas Muhammadiyah Yogyakarta
}

\section{Article Info}

Keyword:

Police Image; Genre Analysis,

Sacralization; Representation; Film

\begin{abstract}
The image of the police is understood in various ways. In the news, the police are often presented with a negative image. However, there is a tendency for the police to be sanctified as saints in the film. This article attempts to explain the forms of sacralization of police images displayed in cinema. Uses genre analysis to answer the research questions. The Police Movie Festival in 2017-2019 was the chosen research object since the Indonesian National Police organize this film festival, it will be seen how they want to be shown in the film. As a result, the Police Movie Festival winners increasingly sanctify the police's image as heroes, patriotic, humanist, and a tolerant and pluralist figure. These images that emerge can obscure that the police also often justify violence when dealing with civilians who are supposed to be the parties they protect.
\end{abstract}

Copyright (C) 2021 Interaksi: Jurnal Ilmu Komunikasi. All rights reserved.

\section{PENDAHULUAN}

Kepolisian Republik Indonesia tetap berupaya untuk membangun citra positif karena masih banyak perilaku polisi yang anomali dalam menjalankan tugasnya. Akibatnya, citra polisi masih buruk di masyarakat. Polling opini yang dilakukan Kompas, pada tahun 2001 hingga 2009 menunjukkan citra buruk Polri dari 62\% menjadi 38\% (Sutrisno, 2016).

Media dalam memberitakan kinerja Polisi justru menguatkan citra negatif institusi kepolisian (Duta, 2017; Farjina, 2017). Sebagai contoh, polisi kerap digambarkan dengan frame yang kurang baik di media cetak. Berdasarkan penelitian yang dilakukan oleh Tayipnapis (2019) tentang Pemberitaan Polisi di Majalah Tempo menunjukkan bahwa Tempo sebagai media massa sering kali menilai polisi secara negatif dengan menyoroti buruknya struktur kepolisian. Lebih lanjut Kartika (2014) menyatakan bahwa citra polisi belum sepenuhnya dipersepsikan secara positif oleh publik karena jumlah foto satir yang mencemarkan nama baik polisi lebih banyak daripada jumlah foto yang menampilkan citra humanis polisi.
Namun, film menggambarkan institusi polisi secara berbeda. Film-film cenderung membangun sosok polisi sebagai pahlawan pemberantasan kejahatan. Penelitian Faddli dan Rochim (2015) tentang citra polisi dalam film Comic 8 menyimpulkan bahwa polisi adalah orang yang tidak cacat hukum. Penelitian Iqbal (2019) dalam film 22 Menit menunjukkan polisi sebagai abdi negara yang bertanggung jawab dan institusi kepolisian menjadi institusi negara yang paling tegas dalam mengatasi masalah pelanggaran hukum. Umumnya film membangun citra polisi sebagai mereka yang mampu menjalankan tugasnya untuk mengabdi dan melindungi masyarakat. Sutrisno (2016) menyebutnya sebagai sakralisasi citra polisi.

Dalam bukunya, Sutrisno (2016) menjelaskan bahwa Polri semenjak era reformasi telah mencoba untuk membuka diri dengan berkolaborasi dengan beberapa lembaga independent seperti KontraS. Akan tetapi lembaga tersebut terkadang menjadi narasumber untuk memberitakan buruknya di media. Sama halnya dengan media pers yang lebih banyak menjalankan perannya untuk "mengkontrol dan mengawasi" kinerja Polri dibandingkan "menginformasikan" program kerja Polri (Sutrisno, 2016). Alhasil Polri bisa menggunakan 
film sebagai alternatif pembanding untuk membangun wacana baru mengenai sisi lain citra polisi sebagai institusi maupun sebagai individu.

Penelitian ini akan menganalisis simbol sakralisasi citra polisi dalam film yang menjadi salah satu upaya Kepolisian Republik Indonesia untuk memperbaiki citra polisi di media. Polisi sendiri sejak beberapa tahun terakhir memiliki proyek strategis untuk membangun image dengan melibatkan peran media secara aktif. Divisi Humas Polri secara terbuka menyatakan program-program media diproduksi dan didukung untuk menaikkan isu positif dan menekan isu negatif. Bahkan polisi tak segan menggelontorkan dana yang cukup besar untuk itu. Misalnya, dana Pengadaan Jasa Produksi Komik Strip dan Animasi Edukasi tahun 2020 adalah sebesar 3,5 Milyar, Pengadaan Jasa Produk Meme dan Video Edukasi sebesar 2,7 M (Menjadi Pahlawan, 2020), atau anggaran promosi untuk media sosial di tahun 2020 sebesar 2,7 Milyar (Tuai Kritik, 2020).

Konstruksi image positif sebagai aparat yang bisa diandalkan tidak hanya dalam bentuk komik strip, animasi, dan promosi di media sosial. Polisi juga aktif mengontrol isu-isu terkait polisi di media penyiaran maupun media cetak melalui unit satuan Divisi Humas Mabes Polri. Menurut Peraturan Kepala Kepolisian Negara Republik Indonesia No. 6 tahun 2017 tentang Susunan Organisasi Dan Tata Kerja Satuan Organisasi Pada Tingkat Markas Besar Kepolisian Negara Republik Indonesia, divisi Humas Mabes Polri sebagai unsur pengawas dan pembantu pimpinan di Mabes Polri memiliki tugas untuk melakukan manajemen media baik di media penyiaran, media cetak maupun media digital.

Untuk melegitimasi fungsi dan kinerja Polri maka divisi Humas Mabes Polri rutin melakukan media visit ke hampir seluruh kantor berita baik media penyiaran, media cetak, maupun kantor portal berita online. Selain itu di media digital, Humas Mabes Polri juga menggiatkan interaktivitas di akun media sosial resmi milik Polri. Untuk mempersiapkan konten yang mampu merepresentasikan sisi positif Polri dengan gaya komunikasi yang kekinian tanpa menghilangkan kultur institusi maka Polri juga rutin memberikan pelatihan dan kursus singkat seperti manajemen media, jurnalistik, videografi, fotografi, pembuatan meme, infografis dan produksi produk kreatif lainnya bagi pegawai humas di internal kepolisian. Pelatihan itu diberikan kepada humas Polri dari level Mabes, Polda, Polres dan Polsek agar seluruh staf humas Polri memiliki kompetensi dan keahlian dalam memanfaatkan segala media komunikasi (Kapolri Minta, 2017). Langkah kreatif lain yang dilakukan oleh Humas Mabes Polri untuk mempertegas citra positif Polri yakni dengan membiayai produksi film polisi, seperti 22 Menit (2018), Pohon Terkenal (2019), Hanya Manusia (2019), dan Sang Prawira (2019). Masih tentang film, tercatat sejak tahun 2014, Divisi Humas Mabes Polri menyelenggarakan Police Movie Festival (PMF).

Program sakralisasi citra positif tersebut ternyata berhasil menaikkan citra polisi di masyarakat. Hasil survey Litbang Kompas pada tahun 2018, tingkat kepuasan masyarakat terhadap Polri meningkat dari 46,7 persen pada 2014 menjadi 82,9 persen (Survey Kompas, 2018). Sementara menurus hasil survey dari Cyrus Network, sejumlah 61\% responden menilai kepercayaan terhadap polisi meningkat. Sebanyak 71\% responden menilai polisi makin kuat, 68\% responden menganggap polisi makin solid, dan $62 \%$ polisi dinilai responden semakin bisa dipercaya. Hasil ini menempatkan polisi berada di urutan ketiga lembaga negara yang dipersepsi baik oleh publik (Cyrus Network, 2020).

Adanya upaya sakralisasi citra polisi dalam film mendorong peneliti untuk melakukan analisis mendalam terhadap bentuk-bentuk sakralisasi citra polisi yang muncul di dalam film-film yang bertema polisi. Untuk itu peneliti secara khusus menaruh perhatian pada produk penting polisi yang diselenggarakan secara rutin tiap tahun, yaitu Police Movie Festival (PMF).

Di dalam situs Police Movie Festival (https:// policemoviefestival.com), tertulis bahwa PMF adalah festival film pendek yang diselenggarakan oleh Kepolisian Republik Indonesia dengan menyertakan unsur kepolisian yang tepat di setiap film pendek atau animasi yang masuk. PMF menjadi wadah bagi para pembuat, sineas dan masyarakat untuk mempererat hubungan baik dengan polisi. Melalui beragam film yang diikutsertakan, masyarakat diharapkan dapat 
melihat sisi lain polisi yang jarang terlihat di mata masyarakat awam. Kegiatan ini diselenggarakan oleh Kepolisian Republik Indonesia sejak tahun 2014 yang diikuti oleh finalis dari berbagai kalangan. Juri dalam kompetisi ini juga profesional dari industri perfilman, bukan dari internal kepolisian sehingga perlu dianalisis bagaimana masyarakat, baik finalis maupun juri, saat memotret citra polisi dalam kompetisi film yang diselenggarakan Polri. Akankah sosok polisi akan selalu muncul sebagai pahlawan tanpa cela atau memunculkan citra lainnya? Untuk memahami bentukbentuk sakralisasi citra yang ingin dibangun, maka peneliti melakukan analisis genre terhadap film-film pemenang PMF tahun 2017-2019, baik kategori film pendek maupun film animasi.

\section{KAJIAN PUSTAKA}

Film tidak hanya berfungsi sebagai media hiburan, karena film juga menjadi sarana representasi dan konstruksi dari realitas yang terjadi dalam kehidupan sehari-hari. Film menghadirkan potret atau citra melalui bentuk simbolik yang sarat makna. Berbagai elemen naratif dan estetika merepresentasikan objek atau peristiwa tertentu. Orang sering menerima bentuk simbolik yang ditampilkan secara dramatis pada film sebagai sebuah kebenaran otentik. Padahal film memiliki realitas tersendiri yang dibentuk berdasarkan ideologi dan kepentingan tertentu. Begitu juga dengan film yang menampilkan citra dan narasi tentang polisi.

Pautz membenarkan bahwa dalam menampilkan citra kepolisian, media tidak membebaskan diri dari kenyataan, tetapi juga tidak merefleksikannya (Pautz, 2016). Terdapat pembiasan realitas di industri media, seperti organisasi media, kerangka ideologis personel dan khalayak kreatif, serta perubahan politik dan kekuatan ekonomi. Faktor-faktor tersebut mempengaruhi konstruksi citra polisi dalam film tersebut (Reiner, 2010).

Dalam merepresentasikan citra polisi, hal-hal yang terkait dengan identitas ras, etnis, jenis kelamin, golongan, atau agama tidak dapat dihindari. Kebanyakan dalam film-film Hollywood, orang kulit berwarna ditampilkan sebagai orang yang brutal dan tidak dihormati oleh polisi kulit putih (Crawford, 1999). Gangster atau pengedar narkoba adalah orang Afrika-Amerika atau Amerika Latin; imigran ilegal adalah orang Asia atau Amerika Latin, sedangkan teroris adalah orang keturunan Timur Tengah. Etnis minoritas mewakili penjahat, sedangkan tokoh polisi adalah orang kulit putih.

Representasi yang buruk tentang kelompok minoritas diteliti oleh Hall akibat ketertarikannya pada masalah minoritas yang muncul dalam film-film Karibia (Hall, 1989). Hall berfokus pada masalah identitas dan representasi yang muncul dalam film. Ia menekankan konsep sinema sebagai praktik pelafalan dan menggambarkan diaspora sebagai titik strategis (Prysthon, 2016). Kelompok minoritas seringkali ditampilkan sebagai perbedaan, dengan stereotip dan stigma tertentu. Sedangkan kelompok dominan ditampilkan dengan representasi yang menguntungkan mereka.

Untuk memahami sebuah film, peneliti tidak hanya fokus pada film itu sendiri, tetapi juga pada bentuk budaya secara keseluruhan. Hall pernah menyarankan perlunya dialog yang lebih luas antara identitas budaya dan representasi sinematik. Hall menjelaskan lebih lanjut sebagai berikut:

The first position defines 'cultural identity' in terms of the idea of one, shared culture, a sort of collective 'one true self', hiding inside the many other, more superficial or artificially imposed 'selves', which people with a shared history and ancestry hold in common. [...] This second position recognizes that, as well as the many points of similarity, there are also critical points of deep and significant difference which constitute 'what we really are': or rather- since history has intervened -'what we have become'. (Hall, 1989:69-70)

Hall tertarik untuk memahami lebih spesifik bagaimana ras dan kelompok etnis direpresentasikan dengan menggunakan analisis teks pada artikel surat kabar dan majalah, acara televisi dan film. Dari sudut pandang sinema, konsep stereotipe dan proses terkait merupakan hal yang perlu diperhatikan dalam representasi. 
Hall menyatakan bahwa stereotipe itu sederhana, jelas, lebih mudah diingat, mudah dipahami, dan dikenal luas. Stereotipe juga mereduksi sesuatu atau seseorang, membesar-besarkan dan menyederhanakannya, mengoreksinya tanpa kesesuaian, dan berupaya untuk melanggengkannya (Hall, 1997). Setidaknya ada tiga karakteristik stereotip yang digarisbawahi. Pertama, stereotip mengurangi, membuat, menaturalisasi, dan mengoreksi perbedaan. Kedua, stereotip menggunakan strategi pemisahan. Stereotip membagi antara apa yang dapat diterima dan yang tidak, atau strategi inklusi dan eksklusi. Akibatnya, ada upaya untuk mengecualikan segala sesuatu yang berbeda. Dengan kata lain, stereotip memelihara tatanan sosial dan simbolik. Ketiga, stereotipe cenderung muncul ketika ada praktik kekuasaan dominan (Hall, 1997: 258). Konsep stereotipe yang dikemukakan Hall memiliki implikasi yang jelas bagi kajian film, terutama mengenai analisis kelompok marginal yang kurang terwakili.

Terdapat beberapa penelitian terkait penggambaran citra polisi di media yang telah dilakukan selama ini, namun masih terdapat beberapa ruang untuk menggali masalah ini secara komprehensif sebagai fokus utama penelitian ini. Contoh-contoh penelitian tentang konstruksi polisi di media dapat dilihat pada bagan berikut:

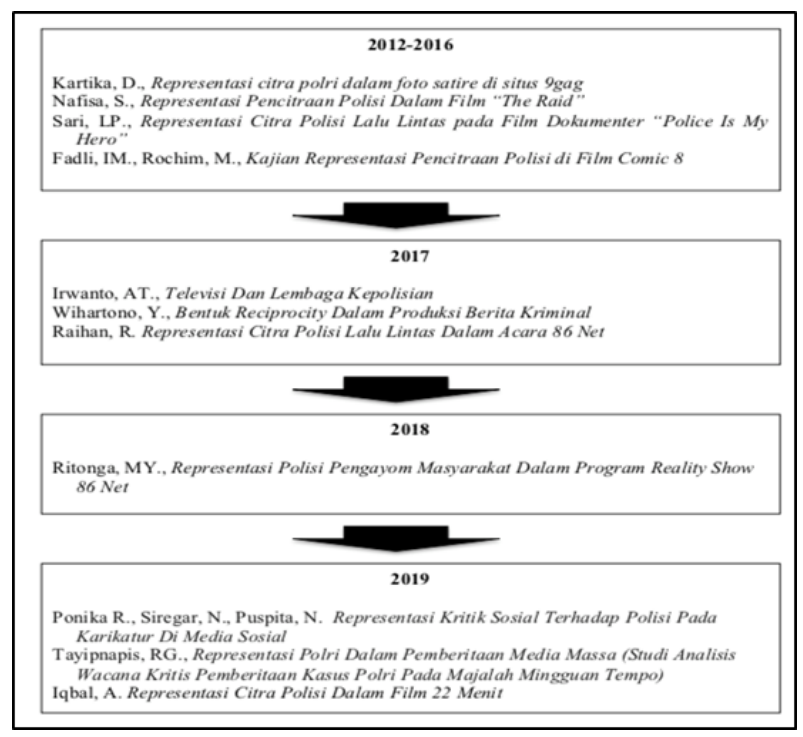

Berdasarkan bagan di atas, terlihat bahwa penelitian terkait isu kepolisian dan media hanya dilakukan dalam ruang lingkup yang sempit dan spesifik. Tulisan ini menawarkan sesuatu yang berbeda dengan penelitian-penelitian yang dilakukan sebelumnya, dengan melihat secara lebih seksama tentang elemenelemen yang muncul dalam film-film yang merepresentasikan polisi.

\section{Metode Penelitian}

Penelitian ini menggunakan metode analisis genre. Metode ini menjadi tool of analysis sehingga peneliti dapat mengidentifikasi dan menganalisis konvensi generik yang muncul dalam film-film pemenang PMF tahun 2017-2019. Menurut Thwaites et al. (1994: 95), analisis genre mengarahkan pada pembacaan genre, yang terutama berfokus pada efek tekstual dan kontekstual. Dalam hal ini, proses analisis tidak hanya membaca struktur atau elemen yang direpresentasikan oleh genre tertentu tetapi juga membantu peneliti untuk membaca dan menganalisis pilihan-pilihan materi dari genre yang dipilih dan hubungan konteks sosialnya dalam proses produksi makna.

Dalam melakukan analisis, peneliti menggunakan metode analisis genre seperti yang telah dieksplorasi oleh Jane Stokes (2013: 149). Stokes mengidentifikasi beberapa elemen, seperti ide dasar, karakter, setting, ikonografi, dan peristiwa naratif, yang muncul dalam film-film pemenang PMF tahun 2017-2019. Dengan menganalisis kelima elemen tersebut, peneliti dapat mengidentifikasi citra polisi yang diinginkan yang dibangun dalam film tersebut.

Daftar film-film pemenang PMF tahun 20172019 yang dianalisis dalam tulisan ini terangkum dalam tabel sebagai berikut:

Tabel 1. Daftar Film-Film Pemenang PMH 2017-2019 Kategori Film Pendek dan Animasi

\begin{tabular}{|l|l|l|}
\hline $\begin{array}{l}\text { PMF } \\
\text { Tahun }\end{array}$ & $\begin{array}{l}\text { Kategori Film } \\
\text { Pendek }\end{array}$ & $\begin{array}{l}\text { Kategori } \\
\text { Animasi }\end{array}$ \\
\hline 2017 & $\begin{array}{l}\text { Juara: } \\
\text { Kau adalah Aku } \\
\text { yang Lain (Anto } \\
\text { Galon) } \\
\text { The Underdog (JC } \\
\text { Production) } \\
\text { Peci Ajaib (RTF } \\
\text { Production) }\end{array}$ & $\begin{array}{l}\text { Juara: } \\
\text { 1. Darmuji } 86 \\
\text { (Karya Allie } \\
\text { Studio) }\end{array}$ \\
$\begin{array}{l}\text { 2. The Ant King- } \\
\text { dom (Respro } \\
\text { Animation Stu- } \\
\text { dio) } \\
\text { 3. Ego (Do It } \\
\text { Animation) }\end{array}$ \\
\hline
\end{tabular}




\begin{tabular}{|c|c|c|}
\hline 2018 & $\begin{array}{l}\text { Juara: } \\
\text { Humanis (AKBP. } \\
\text { Phileman Ginting) } \\
\text { Persepsi } \\
\text { (Satlantas Aceh } \\
\text { Besar) } \\
\text { Sebuah Jawaban } \\
\text { (Nuan Gantana) }\end{array}$ & $\begin{array}{l}\text { Juara: } \\
\text { Time (Luwdo } \\
\text { Animation) } \\
\text { Pacarku } \\
\text { (Musang Putih } \\
\text { Animation Stu- } \\
\text { dio) } \\
\text { Kisah Sore Ini } \\
\text { (Light Produc- }\end{array}$ \\
\hline 2019 & $\begin{array}{l}\text { Juara: } \\
\text { Cikal (Jane } \\
\text { Chrisdianty) } \\
\text { Tersembunyi } \\
\text { (Suwanda) } \\
\text { Di Balik Tameng } \\
\text { (Darius Manihu- } \\
\text { ruk) }\end{array}$ & $\begin{array}{l}\text { Juara: } \\
\text { Strong (Reisal } \\
\text { Prabaya) } \\
\text { Unlikely Part- } \\
\text { nership } \\
\text { (Chandra Hadi } \\
\text { Suparman) } \\
\text { Teror (M. } \\
\text { Fachmi Al Ra- } \\
\text { syid) }\end{array}$ \\
\hline
\end{tabular}

\section{TEMUAN DAN DISKUSI}

\section{Citra Polisi dalam Film Pemenang PMF 2017-2019}

Film-film di dalam genre yang sama cenderung memiliki karakteristik yang sama. Tujuan penggunaan metode analisis genre adalah untuk mengetahui kecenderungan struktural dalam film-film bertema polisi. Berdasarkan identifikasi konvensi generik, peneliti membagi bentuk-bentuk sakralisasi citra polisi sebagai berikut:

\section{Polisi Sebagai Pahlawan Sejati}

Beberapa film memiliki ide yang sama, yaitu ada masalah, biasanya terkait dengan tindak kekerasan (terorisme, penculikan/perdagangan anak, demonstrasi, premanisme, dan chaos). Menghadapi kekerasan, polisi tampil dengan persenjataan dan alat pelindung lengkap. Polisi hadir sebagai penyelamat, problem solver, namun juga dengan kekerasan (baku tembak dan perkelahian). Polisi memiliki tanggung jawab sebagai garda depan melawan kejahatan. Di akhir cerita, polisi berhasil memenangkan pertarungan.

Polisi dalam film tampil dengan seragam, terkadang lengkap dengan senjata dan pakaian pelindung. Penampilan polisi dapat dilihat pada gambar berikut:

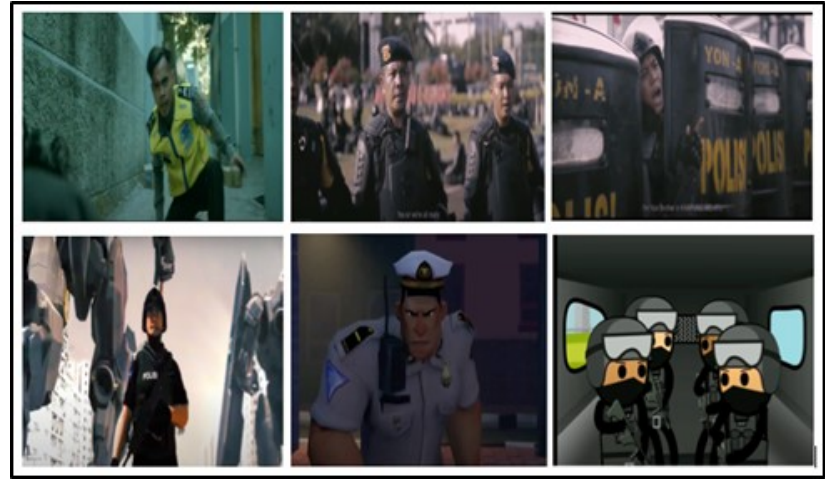

Gambar 1. Penampilan Polisi dengan seragam, pakaian pelindung dan senjata

Citra polisi sebagai pahlawan sejati merupakan implementasi dari ideologi maskulinitas hegemonik. Connell (2005: 77-79) memperkenalkan konsep maskulinitas hegemonik sebagai gambaran tentang bagaimana menjadi laki-laki menurut budaya dominan. Konstruksi tersebut dilegitimasi oleh budaya patriarki yang heteronormatif untuk mengamankan posisi laki-laki terhadap perempuan. Konsep maskulinitas hegemonik tidak bersifat universal, namun tergantung dari rezim yang berkuasa. Ketika rezim kekuasaan berubah, rezim baru membangun hegemoni baru.

Maskulinitas hegemonik di Indonesia terkait dengan sejarah budaya militeristik yang dominan pada masa Orde Baru. Yang menjadi maskulinitas hegemonik adalah sekelompok orang yang menjalankan kepemimpinan patriarki dan diwakili oleh sosok "Bapak". Bapak adalah simbol laki-laki yang berkuasa atas perempuan dan anak-anaknya. Dalam politik Orde Baru, "Bapak" mengendalikan pengikut setianya; model hubungan itu kemudian disebut sebagai Bapakism (Pye dan Pye, 1985: 306).

Bapakisme adalah priyayi Jawa dari kalangan atas yang menjadi sosok maskulin ideal. Soeharto mengangkat dirinya sebagai pemegang kekuasaan tertinggi di Indonesia dengan menyebut dirinya sebagai Bapak Pembangunan Indonesia. Ia memiliki kekuasaan penuh atas istri dan anak-anak atau laki-laki di bawah dominasinya, dan juga di sektor bisnis, serta negara. Soeharto kembali menanamkan hegemoni bahwa kekuasaan yang dimilikinya semata-mata merupakan kodrat Tuhan yang tidak perlu dipertanyakan lagi (Clark, 2004: 118). Maskulinitas hegemonik yang 
dikonstruksi oleh kepemimpinan Soeharto identik dengan maskulinitas militer (Handajani, 2010) karena ia seorang jenderal militer senior. Otoritasnya mendapat dukungan kuat dari militer. Berdasarkan sejarah, militerisasi memiliki pengaruh yang signifikan dalam membentuk konstruksi maskulin di Indonesia.

Pasca jatuhnya Orde Baru, ada beberapa gagasan progresif, terutama dari budaya populer, menantang hegemoni ideal yang sudah mapan (Paramadita, 2007; Handajani, 2010; Clark, 2004). Namun, beberapa institusi masih mengadopsi gagasan maskulinitas militer, termasuk institusi kepolisian. Pada masa Orde Baru, polisi dimasukkan ke dalam institusi militer. Akibatnya, ketika polisi dipisahkan dari militer, pandangan yang berdasarkan ideologi militer masih memiliki pengaruh yang kuat dalam membangun citra laki-laki yang maskulin.

Maskulinitas militer dikaitkan dengan kekuatan fisik, kekuasaan, agresivitas, kemandirian, disiplin, potensi seksual, kekerasan, heteroseksualitas, kekebalan, komitmen pada misi, dan kemampuan menghadapi situasi (Kachtan, 2016). Penulis menemukan beberapa karakter ini melekat pada sosok polisi dalam film.

Karakter maskulin polisi mayoritas dilekatkan pada sosok polisi laki-laki. Lalu bagaimanakah sosok polisi perempuan atau biasa diistilahkan dengan polwan (polisi wanita). Polisi sendiri adalah profesi maskulin. Perempuan yang menjadi polisi, secara fisik, jika melihat pada pakaian seragam yang dikenakan, sisi maskulinnya memang menonjol. Namun secara peran dan sifat, polisi perempuan memiliki perbedaan dengan polisi laki-laki. Beberapa film menampilkan sosok polisi perempuan. Namun polisi perempuan bukan menjadi tokoh utama. Misalnya film Tersembunyi, polisi perempuan di akhir cerita ditampilkan bersama polisi lakilaki menjelaskan tentang tertib berlalu lintas. Film Strong juga menampilkan perempuan sebagai salah satu anggota tim polisi yang bertugas mengatur kode SOS.

Bahkan dalam film Peci Ajaib, polisi perempuan justru dimanfaatkan untuk menghadapi pelanggaran lalu lintas yang menolak ditilang. Setelah berhadapan dengan polisi perempuan yang cantik, sang pelanggar langsung berubah pikiran. Polisi perempuan, tak ada bedanya dengan profesi yang identik dengan perempuan lainnya, memanfaatkan citra tubuhnya yang identik dengan keindahan dan kecantikan sebagai daya tarik. Terkait dengan hal ini Irjen Setyo Wasisto, mantan kepala divisi Humas Mabes Polri, pernah mengatakan bahwa jika ada persyaratan cantik bagi calon polwan (Polri Akui, 2018). Sementara persyaratan yang sama tidak diberlakukan bagi calon polisi lakilaki.

Porsi polisi perempuan yang cukup besar, meski bukan pemeran utama ada di film Persepsi. Polisi perempuan tampil sebagai atasan polisi pemeran utama yang mengkoordinir program pembentukan citra polisi lalu lintas yang ramah. Polisi perempuan bertanggung jawab memproduksi program perbaikan citra polisi lalu lintas.

Polisi dalam film masih identik dengan lakilaki. Polisi perempuan hanya sebagai pelengkap, bukan tokoh utama. Perannya juga banyak ditempatkan pada hal-hal yang lebih feminin, seperti hal-hal yang terkait dengan ketertiban atau citra polisi yang ramah. Posisi polisi perempuan tersebut juga ditegaskan dalam kebijakan polri.

Dalam perayaan hari ulang tahun Polwan yang ke 72 pada tanggal 1 September 2020 mengambil tema "Polwan Siap Mewujudkan Kamtibmas Kondusif, Masyarakat Semakin Produktif." Makna dari tema tersebut adalah bahwa Polwan berkomitmen meningkatkan kinerja dan profesionalisme pelaksanaan tugas Polri untuk mewujudkan stabilitas Kamtibmas yang semakin kondusif guna mendukung produktifitas masyarakat. Namun yang menarik, polisi perempuan memiliki tambahan peran. Sebagai seorang perempuan, mereka dibebani sebagai pelopor bagi perempuan lainnya untuk mengembangkan dirinya sebagai ibu bagi anak-anaknya dan sebagai pilar bagi tumbuhnya generasi muda yang berkualitas dan menjadi garda terdepan dalam memperjuangkan hak-hak perempuan (Kapolda Sultra, 2020).

\section{Polisi Yang Patriotik (Cinta tanah air)}

Karakter maskulin polisi tampil sejajar dengan simbol patriotisme. Istilah "patriotisme" dilekatkan 
pada seseorang atau anggota kelompok pada kelompoknya dan tanah tempat mereka berada (Bar-Tal dan Staub, 1997). Saat ini, tanah sering mengacu pada negara, seperti yang dijelaskan oleh Gilbert (dalam Nincic dan Ramos, 2009) bahwa patriotisme adalah cinta pada negara. Parker (2010) menyatakan adanya kompleksitas dalam memahami patriotisme karena konsep tersebut terbagi menjadi blind patriotism dan symbolic patriotism. Patriotisme simbolik merepresentasikan keterikatan yang relatif abstrak dan afektif pada bangsa dan nilai-nilai intinya.

Lewat emblem, bendera dan lagu kebangsaan, simbol patriotisme tumpang tindih dengan simbol kebangsaan. Dalam ajang PMF, para pemenang menunjukkan bendera dan memainkan lagu kebangsaan untuk menggambarkan patriotisme. Ilustrasi beberapa adegan yang menunjukkan Bendera merah putih adalah sebagai berikut:

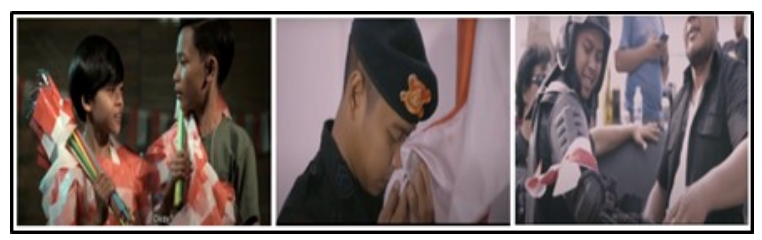

\section{Gambar 2. Simbol-simbol patriotisme}

Bendera merah putih menganut nilai kepahlawanan, nasionalisme, dan patriotisme karena berkaitan dengan sejarah bangsa. Bendera tersebut menceritakan kisah heroik dan aksi revolusioner di era kolonial. Bendera merah putih pertama kali digunakan sebagai properti untuk melawan kolonialisme Belanda. Untuk itu, bendera merah putih melambangkan semangat rakyat untuk merdeka dari penjajahan Belanda. Ratusan ribu pejuang tewas, dan bendera merah putih adalah simbol perjuangan. Pada Hari Kemerdekaan 17 Agustus 1945, akhirnya bendera merah putih resmi dikibarkan. Namun, tindakan pejuang yang paling patriotik adalah pada perang untuk mempertahankan kemerdekaan yang terjadi di Hotel Orange, Surabaya, pada tanggal 10 November 1945. Belanda mengibarkan bendera merah-putih-biru, para pejuang berusaha merobek biru. Pejuang berhasil hingga tinggal warna merah putih yang berkibar. Aksi tersebut membawa korban yang cukup besar. Tindakan perobekan bendera tersebut merupakan tindakan heroik dan melambangkan perjuangan mempertahankan negara.

Selain bendera, film tersebut juga memutar dua lagu kebangsaan berjudul Ibu Pertiwi dan Indonesia Pusaka. Ibu Pertiwi adalah lagu patriotik Indonesia yang digubah oleh Kamsidi Samsuddin. Liriknya tentang "Ibu Pertiwi" yang diartikan sebagai "negara ibu", personifikasi bangsa Indonesia. Arti dari lagu ini adalah konsep kenegaraan. "Ibu Pertiwi" adalah personifikasi negara yang harus dipertahankan. Dengan demikian, lirik lagu tersebut mendasari sikap heroik dan menyulut semangat patriotik sebelum, selama, dan setelah kemerdekaan. "Ibu Pertiwi" melambangkan pengorbanan jiwa raga, hidup atau mati, bukti semangat pengabdian dan cinta tanah air. Film pemenang ketiga PMF 2019, Di Balik Tameng, lagu kebangsaan dimainkan sebagai backsound saat adegan rekonsiliasi antara pengunjuk rasa dan polisi yang menjaga keamanan.

Ismail Marzuki menggubah lagu Indonesia Pusaka. Liriknya bercerita tentang pujian dan cinta untuk Indonesia. Dalam film Cikal, juara I PMF 2019, seorang anak yang menjadi polisi saat besar nanti, memainkan lagu ini dengan sengaja untuk mendamaikan dua kelompok yang akan bertarung. Pemutaran lagu kebangsaan itu melatarbelakangi peristiwa yang sama, konflik dan upaya berdamai. Diindikasikan bahwa lagu kebangsaan melambangkan kedamaian dan persatuan, sebagai implementasi cinta tanah air.

Simpson (1993) mengatakan bahwa patriotisme memiliki setidaknya tiga unsur, yaitu cinta tanah air, keinginan untuk menyejahterakannya, dan kemampuan untuk mengabdi dalam memelihara dan mempertahankan negara. Patriotisme meliputi keutamaan, seperti percaya diri, menjunjung tinggi prinsip, menghargai, dan berbakti. Tiga elemen patriotisme tampil dalam citra polisi. Polisi adalah pahlawan patriotik. Mereka mencintai negara dan karena mereka menyelamatkannya dari para penjahat yang mengancam persatuan. Polisi baik hati, kuat, dan menjaga jati diri bangsa.

\section{Polisi Yang Berperikemanusiaan}

\subsection{Maskulinitas Baru ala Polisi}

Pada bagian sebelumnya, penulis telah men- 
jelaskan karakter maskulin yang militeristik sebagai salah satu citra polisi yang ditampilkan, Namun maskulinitas polisi tidaklah melulu militeristik. Polisi dalam film adalah makhluk yang sempurna. Polisi tidak hanya tampil dalam persona militer, tetapi polisi juga digambarkan secara humanis. Polisi adalah orang yang baik, sering membantu orang lain yang membutuhkan atau dekat dengan anak-anak. Polisi juga selalu bersedia memaafkan kesalahan orang lain, bahkan lawannya.

Dalam film, polisi digambarkan sebagai sosok yang baik dan suka menolong yang lemah. Misalnya saja dalam film Di Balik Tameng, polisi diceritakan memberikan nasi pada orang yang kelaparan dan menolong orang yang terluka. Polisi juga rela berkorban demi tanggung jawab profesi maupun melindungi pihak lain (The Underdog), walaupun musuh sekalipun (di film Time, polisi rela berkorban untuk menolong teroris yang akan meledakkan bom). Yang cukup menonjol, banyak film pemenang PMF yang mencitrakan polisi yang cinta keluarga (The Underdog, Persepsi), dan dekat dengan anak-anak (Darmuji 86, Humanis, Sebuah Jawaban, Kisah Sore Ini, dan Cikal).

Bersikap baik kepada orang lain dan lebih memperhatikan anak-anak yang dekat dengan feminitas, atribut yang melekat pada perempuan. Namun, Beynon (2002) menyebutkan konsep maskulinitas baru untuk menggambarkan laki-laki baru. Laki-laki baru mengacu pada laki-laki di tahun 1980-an. Konsep baru maskulinitas mencoba untuk menjauh dari atribut tradisional maskulinitas dan patriarki (Beynon, 2002: 99). Salah satu karakter laki-laki baru adalah pelindung atau pengasuh. Penggambaran laki-laki yang melindungi sesama muncul pada tahun 1970-1980-an sebagai respon terhadap gerakan feminis yang memperjuangkan kesadaran untuk menjadi laki-laki yang lebih peduli dan mengasuh. Karakter laki-laki baru juga muncul dalam film.

\subsection{Polisi Sahabat Anak}

Sebagian besar film-film pemenang PMF menampilkan karakter anak-anak. Meski bukan sebagai tokoh utama atau inti cerita, kehadiran anak-anak menjadi penanda penting dalam citra polisi. Anak-anak dalam film merepresentasikan perspektif orang dewasa tentang anak-anak (Buckingham, 1995; Strassler, 1999;
Spyer, 2004 dalam Wibawa, 2008).

Selain itu, dalam film anak-anak tampil sebagai harapan masa depan yang menjanjikan (Jenkins dalam Wibawa: 2008). Kitley (1999) pernah meneliti film Si Unyil menjelaskan bahwa tokoh Unyil dikonstruksi sebagai contoh bagaimana menjadi warga negara yang baik, berwawasan luas dan berkomitmen pada pembangunan nasional. Representasi Unyil sebagai anak Indonesia berdasarkan perspektif negara, dalam hal ini orde baru, masih relevan dalam citra anak-anak di film polisi masa kini.

Anak-anak dalam film polisi juga merepresentasikan apa yang diharapkan polisi atas anak-anak di masa yang akan datang. Dalam film Cikal, dengan alur flashback, seorang polisi bercerita pada anak-anak tentang pengalaman dia dan temannya yang juga menjadi polisi tapi gugur saat menjalankan tugas. Anakanak di film Cikal merupakan sosok polisi di masa depan. Anak-anak ditampilkan cinta damai, cinta tanah air, dan rela berkorban. Karakter-karakter tersebut adalah apa yang dibayangkan oleh orang dewasa (dalam hal ini polisi) sebagai karakter anak-anak yang ideal.

Anak-anak menjadi penting untuk ditampilkan dalam film polisi dalam rangka membangun citra polisi sebagai sosok yang pahlawan yang baik hati dan humanis. Anak-anak yang polos, lemah, tidak berdaya harus selalu dilindungi (Bushati, 2018), dan polisi siap sedia untuk itu. Latar belakang itulah yang mendorong mayoritas film polisi menampilkan tokoh anak. Anakanak bersifat polos dan tidak memiliki daya untuk melindungi dirinya sendiri, sehingga mereka akan selalu membutuhkan bantuan orang dewasa. Polisi hadir untuk mengisi posisi tersebut.

Anak-anak memang penting untuk polisi. Polisi bahkan mempunyai program khusus yang diberi nama "Polisi Sahabat Anak". Program ini bertujuan untuk menanamkan kedisiplinan dan kepedulian lingkungan sejak dini. Lewat program tersebut polisi mengajak anak-anak untuk berbiasa berperilaku disiplin dalam berlalu lintas (Program Polisi, 2020). Program ini juga bertujuan untuk menanamkan dan menumbuhkan rasa cinta anak-anak pada polisi, menghilangkan citra polisi yang terbangun selama ini sebagai sosok yang kasar dan kejam (Giat Polsanak, 2014). Pencitraan polisi 
yang dekat dengan anak-anak efektif dalam mengangkat reputasi polisi sebagai figur pelindung yang baik hati.

\section{Polisi Yang Toleran dan Pluralis}

Simbol-simbol pluralisme dihadirkan dalam film-film polisi untuk menampilkan citra polisi yang toleran dan pluralis. Simbol-simbol yang muncul dalam film adalah simbol agama, simbol etnis, dan simbol persatuan. Secara konseptual, pluralisme adalah sebuah pengakuan terhadap keberagaman (Yumatle, 2015). Pengakuan akan keberagaman berimplikasi pada adanya pengakuan kebebasan berpikir dan berkeyakinan. Dalam masyarakat yang memiliki keberagaman suku, golongan, agama, hingga pandangan hidup diperlukan kepribadian yang matang dari seseorang dan sekelompok orang untuk hidup secara toleran. Kepribadian inilah yang ingin dicitrakan oleh polisi, bahwa polisi senantiasa toleran terhadap segala keberagaman.

Terdapat dua tema besar dalam film polisi kala menampilkan keberagaman, yaitu keberagaman agama dan etnis. Tema keberagaman beragama terdapat dalam film "Kau Adalah Aku Yang Lain" dan "The Underdog". Keduanya memiliki kesamaan, yaitu sama-sama menunjukkan polisi yang toleran di antara perbedaan agama Islam dan Nasrani. Simbol-simbol agama Islam dan Nasrani dimunculkan, yaitu rosario, salib, sajadah, adzan, sholat, doa-doa, babi dan alkohol. Toleransi ditampilkan lewat adegan yang mempertemukan simbol-simbol kedua agama tersebut tanpa menimbulkan persoalan. Misalnya saja dalam film The Underdog, dikisahkan Femmy, anak seorang polisi beragama Nasrani yang berpidato di depan kelas sedang menceritakan sahabat ayahnya yang bernama Salim, seorang muslim dengan kalimat sebagai berikut, "Om Salim tidak minum alkohol, tidak makan babi, dan cara berdo'anyapun berbeda dengan kami." Begitu pula dalam film Kau Adalah Aku Yang Lain, terdapat adegan yang memperdengarkan ayat-ayat suci Al-Quran yang dilantunkan peserta pengajian bersanding dengan do'a-do'a Nasrani. Secara narasi kedua film juga memiliki kesamaan, yaitu persahabatan atau saling menolong antara mereka yang berbeda agama.

Sementara tema keberagaman etnis ditampilkan dalam film Peci Ajaib. Dalam film tersebut digam- barkan pertemuan polisi dengan berbagai etnis, seperti Madura, Batak, dan Tionghoa. Toleransi polisi ditampilkan saat mereka menghadapi pengendara yang melanggar peraturan tapi menolak untuk ditilang. Polisi terlihat mahir menggunakan bahasa daerah yang bermacam-macam. Saat menggunakan bahasa daerah yang digunakan oleh pelanggar dengan memiliki latar belakang dari etnis Batak, Tionghoa hingga Madura, masalah dapat terselesaikan.

Di luar tema keberagaman agama dan etnis, film Ego juga menceritakan polisi yang menghadapi beberapa orang yang beragam secara usia, kelas sosial, jenis kelamin. Polisi diceritakan berhasil mengatasi persoalan ketika mereka semua terperosok dalam lubang tanpa berpihak pada kelompok tertentu.

Selain menampilkan simbol-simbol keberagaman, untuk menampilkan citra polisi yang toleran dan pluralis, film-film polisi juga menampilkan simbolsimbol lain yang merujuk pada persatuan di atas perbedaan. Simbol-simbol pakaian dari berbagai macam etnis dan pakaian burung garuda yang mengacu pada lambang negara (film Darmuji 86), atau tulisan Bhinneka Tunggal Ika (film The Ant Kingdom).

Pluralisme dan toleransi dalam film-film polisi sangat kuat dalam hal simbolisasi. Film polisi merepresentasikan pluralisme sebagai bentuk pencampuran simbol-simbol, terutama simbol agama dan etnis. Filmfilm polisi menunjukkan upaya untuk keluar dari eksklusivisme atau pandangan yang menganggap agamanya (juga etnis dan identitas kelompoknya) sebagai satu-satunya yang paling benar. Ada kecenderungan untuk menampilkan inklusivisme. Namun inklusivisme justru menimbulkan persoalan. Konsep inklusivisme sesungguhnya identik pada hal keberagaman agama, yang meyakini bahwa Tuhan akan membuka jalan bagi semua agama (artinya semua agama mengandung kebenarannya masing-masing), namun tetap menganggap bahwa agamanya-lah yang superior (Thoha, 2005). Konsep ini juga bisa diterapkan pada identitas kelompok lainnya, seperti identitas etnis.

Dalam hal agama, problem inklusivisme dalam film polisi memang tidak begitu tampak. Film The Underdog dan Kau Adalah Aku Yang Lain, yang menceritakan persahabatan dan respek antara pihak- 
pihak yang memiliki agama Islam dan Nasrani, dalam menampilkan kedua agama relatif cukup seimbang. Tidak terlihat adanya penonjolan kebaikan agama yang satu dibanding agama yang lain. Namun jika dilihat pada film-film lainnya yang tidak secara langsung membahas problem perbedaan agama, simbol-simbol Islam terlihat lebih menonjol. Semua film menampilkan polisi sebagai muslim yang saleh. Penampilan mayoritas perempuan di film polisi juga adalah perempuan muslimah yang mengenakan kerudung, mulai anak-anak hingga orang dewasa.

Problem inklusivisme justru terlihat saat menampilkan keberagaman etnis. Film polisi menampilkan beragam etnis dengan porsi dan representasi yang tampak seimbang. Namun dalam film Darmuji 86 terdapat problem representasi (dalam hal ini adalah under representation atau representasi yang merendahkan) terhadap etnis Papua. Darmuji, sang polisi, diceritakan sedang mengawal anak-anak yang sedang menyeberang jalan. Anak-anak tersebut mengenakan pakaian adat dari berbagai daerah, seperti Jawa, Minangkabau, Papua, dan Sulawesi. Darmuji terlihat kesulitan menghadapi kenakalan anak-anak. Kenakalan tersebut antara lain: seorang anak laki-laki berkostum Sulawesi mencabut kumis palsu anak laki-laki lain yang berkostum Jawa hingga ia menangis; atau anak perempuan berkostum Minangkabau tidak sengaja menabrak barisan anak-anak di depannya karena matanya tertutup balutan kerudung besarnya. Namun anak yang berkulit gelap dan menggunakan kostum Papua direpresentasikan memiliki kenakalan yang barbar, ia menggigit tangan Darmuji, seperti terlihat di gambar potongan adegan berikut:

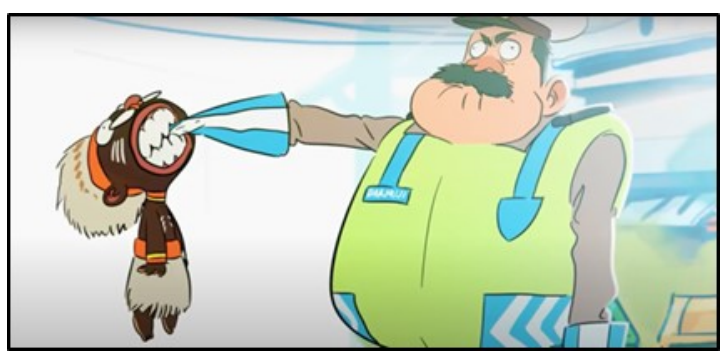

Gambar 3. Adegan anak berkostum suku Papua sedang menggigit tangan Polisi di film Darmuji 86

Pertanyaan yang harus diajukan atas adegan tersebut adalah, mengapa yang dipilih oleh pembuat film adalah anak berkulit gelap yang berkostum Papua saat ada adegan menggigit tangan Darmuji, dan bukan anak yang lain? Banyak penelitian tentang film-film yang mengambil tema Papua mengambarkan representasi orang Papua sebagai sosok yang primitif, bodoh, aneh, suka berkelahi (Rato Rasanae, 2013; Christiani 2017) dan kanibal (Larasati, 2014). Representasi semacam itu akan meneguhkan cara pandang yang merendahkan orang Papua. Hal itulah yang terlihat dalam film Darmuji 86. Pilihan pada anak berpakaian dan berkulit gelap layaknya anak dari etnis Papua yang menggigit tangan polisi menjadi penanda perilaku anak Papua yang aneh dan primitif, atau malah kanibal.

Alih-alih menampilkan keragaman etnis, film Darmuji 86 justru melanggengkan stigma terhadap orang Papua. Inilah contoh dari inklusivitas, meyakini keberagaman sekaligus menganggap kelompoknya sendiri sebagai superior hingga dalam bertindak, disadari maupun tidak disadari, akan cenderung untuk merendahkan kelompok lainnya.

Tindakan polisi terhadap etnis Papua memang diskriminatif. Laporan dari Lokataru Foundation, pada tanggal 19 Agustus 2019, polisi bertindak sewenangwenang dengan menangkap, menahan, dan menggerebek mahasiswa Papua tanpa prosedur hukum yang sesuai dengan nilai hukum dan hak asasi manusia. Sebanyak 43 mahasiswa Papua yang tinggal di Asrama Papua di Surabaya mendapat perlakuan tidak adil dan tidak manusiawi.

\section{Sakralisasi Polisi}

Sakralisasi membuat sesuatu yang sebenarnya bermakna netral, dikonstruksi sedemikian rupa, hingga menjadi sakral, suci atau keramat. Sesuatu yang sakral adalah berkualitas, sehingga sering diagungkan, dieksklusifkan, dan diperlakukan berbeda dari yang lainnya yang termasuk kategori biasa-biasa saja. Dengan demikian, sakralisasi tak ubahnya sebagai sebuah politisasi atau strategi politis untuk membangun persepsi sesuatu yang bermakna netral menjadi bermakna sakral atau bernilai tinggi.

Itulah yang sedang dilakukan oleh polisi. Istilah polisi sesungguhnya bermakna netral. Polisi memiliki tugas sebagai abdi negara yang melindungi 
masyarakat, yang memang sudah sewajarnya jika polisi menjalankan kewajibannya tersebut. Tidak ada yang istimewa. Namun ternyata polisi ternyata memiliki citra yang negatif di masyarakat. Hasil survey Litbang Kompas yang telah dijelaskan diatas menjadi salah satu indikatornya. Maka polisi melakukan upaya-upaya strategis berbujet besar untuk membalik citra buruk polisi menjadi lebih baik.

Membangun citra polisi sebagai pahlawan sejati, patriotis, humanis, dan toleran adalah sebuah upaya sakralisasi, ada upaya melebih-lebihkan figur polisi dalam film-film pemenang PMF. Akibatnya, sakralisasi citra polisi akan mengaburkan masalah yang sebenarnya. Dari film-film, kita membayangkan polisi selalu di sisi yang baik, membela kebenaran dan keadilan. Itulah yang diharapkan masyarakat dari polisi. Namun pada kenyataannya masyarakat menjadi tidak mudah untuk membedakan pihak mana yang baik dan yang buruk. Dari film tersebut, penonton dapat mengetahui bahwa polisi adalah sosok yang baik dari segala sisi.

Namun apakah dalam realitanya demikian? Setidaknya laporan Lokataru Foundation (2019) yang berjudul "Dalam Penegakan Hukum, Aparat Kepolisian (telah) 'Selalu Benar'” tidak menunjukkan hal tersebut. Selain mendiskriminasi mahasiswa Papua, dalam laporan tersebut juga disebutkan bahwa polisi banyak melakukan kekerasan terhadap masyarakat sipil. Demonstrasi mahasiswa dan masyarakat sipil di Jakarta, Bandung, Makassar, Ternate, Medan, dan kota besar lainnya (24-25 September 2019) berakhir dengan kericuhan. Polisi melakukan penggunaan kekuatan yang berlebihan untuk membubarkan demonstrasi dan intimidasi terhadap pengunjuk rasa yang disertai dengan penangkapan sejumlah mahasiswa. Polisi mengerahkan kendaraan taktis dan pasukan anti huru hara untuk membubarkan pengunjuk rasa secara paksa. Langkah ini melampaui batas toleransi hukum di negara demokratis yang menghargai dan melindungi kebebasan berkumpul dan berpendapat. Ratusan orang dilarikan ke rumah sakit akibat terkena gas air mata dan detak jantung. Lima orang tewas selama acara tersebut.

Selain itu polisi juga terlibat dalam pengamanan tanah dan aset perusahaan ketika terjadi konflik agraria antara perusahaan dan masyarakat sekitar. Pihak berwenang melakukan tindakan kekerasan yang brutal. Berdasarkan data Konsorsium Pembaruan Agraria (KPA), terdapat 28 kasus yang melibatkan polisi. Pada tahun 2017 terdapat 612 korban kekerasan (369 dianiaya, 224 dianiaya, enam ditembak, dan tiga dibunuh).

Laporan Lokataru Foundation menunjukkan bahwa polisi tidak berada di pihak yang membela masyarakat. Padahal warga sipil, mahasiswa, atau aktivis yang berkonflik dengan polisi bukanlah orang jahat. Sedangkan penonton melihat lawan polisi dalam film adalah orang-orang jahat. Kekerasan yang dilakukan oleh polisi dalam film-film tersebut telah menormalisasi kekuasaan polisi yang berlebihan dalam realita. Polisi bertindak seolah-olah memiliki legitimasi untuk melakukan kekerasan karena berhadapan dengan orang jahat yang melakukan kekerasan.

\section{KESIMPULAN}

Demi memulihkan citra negatif polisi di media dan di mata masyarakat, polisi melakukan upaya sakralisasi dengan membangun citra sebagai pahlawan, patriotik, humanis, dan toleran. Termasuk dalam pemenang Police Movie Festival juga ada upaya untuk membangun citra polisi yang sakral, polisi menampilkan simbol-simbol maskulinitas, baik yang militeristik sekaligus maskulinitas baru yang mengayomi dan melindungi; bela negara; juga pluralisme. Peristiwaperistiwa naratif juga dibangun dengan menghadirkan musuh, baik berupa ancaman dari orang jahat maupun gesekan-gesekan akibat perbedaan keyakinan dan sikap.

Pemenang dalam PMF 2017-2019 kembali mengsakralkan figur polisi yang lengkap dan agung, memiliki sisi maskulin (pahlawan sejati yang kuat) sekaligus feminin (pelindung, pengayom), berjiwa patriotis dan rela berkorban, serta menghormati dan membela keberagaman agama, etnis dan identitas-identitas lainnya. Tak hanya itu, polisi turut menghadirkan figurfigur pendukung untuk memperkuat citra sakral tersebut, yaitu anak-anak yang direpresentasikan sebagai sosok lemah yang harus dilindungi; dan (polisi) per- 
empuan lewat karakter femininitasnya.

Upaya sakralisasi yang dilakukan Polri dalam penyelenggaraan PMF meninggalkan beberapa masalah, yaitu problem representasi sebagai implikasi atas paham inklusivisme di tengah keberagaman agama dan etnis; dan juga pengaburan fakta bahwa polisi juga sering menghalalkan kekerasan saat berhadapan dengan warga sipil yang seharusnya menjadi pihak yang mereka lindungi.

\section{DAFTAR PUSTAKA}

Bar-Tal, D., and Staub, E. (1997). Patriotism in the Lives of Individuals and Nations, Chicago: Nelson-Hall Publishers

Beynon, J., (2002). Masculinities and Culture, Buckingham dan Philadelphia: Open University Press

Bushati, A. (2018). Children and Cinema: Moving Images of Childhood. European Journal of Multidisciplinary Studies, 3(3), 34-39

Christiani, L. C. (2017). Representasi Identitas Etnis Papua Dalam Serial Drama Remaja Diam-Diam Suka. Jurnal Komunikasi Dan Kajian Media, 1 (1), $15-30$

Clark, M. (2004). "Men, Masculinities, and Symbolic Violence in Recent Indonesian Cinema", Journal of Southeast Asian Studies, 35(1), pp. 113-131

Connel, R. W. (2005). Masculinities, 2nd ed. Berkeley and Los Angeles, California: University of California Press

Crawford, C. (1999). Law Enforcement and Popular Movies: Hollywood as a Teaching Tool in the Classroom. Journal of Criminal Justice and Popular Culture, 6(2), 46-57.

Cyrus Network: Kepercayaan Publik terhadap Polri Meningkat. (2020, 14 Maret). Gatra.com. Diakses pada tanggal 10 Agustus 2020 dari: https://www.gatra.com/detail/news/472058/ hukum/cyrus-network-kepercayaan-publik- terhadap-polri-meningkat

Duta. (2017). Editorial Media Indonesia $\mid$ Polri dalam Buaian Pujian. https://mediaindonesia.com/ editorials/detail_editorials/1108-polri-dalambuaian-pujian

Faddli IM, and M., Rochim. (2015). "Representasi Pencitraan Polisi di Film Comic", Prosiding Manajemen Komunikasi, 1(1), pp. 19-28

Farjina, N. N. (2017). Pencitraan Positif POLRI dalam Acara "86” di Net TV Di Masyarakat Kota Salatiga. Universitas Kristen Satya Wacana.

Giat Polsanak Tumbuhkan Kecintaan Anak Pada Polisi (2014, 11 Februari). Polres Metro Jakarta Selatan. Diakses pada tanggal 11 Agustus 2020 dari: https://www.restrojaksel.info/giat-polsanak -tumbuhkan-kecintaan-anak-pada-polisi/

Handajani, S. (2010). Selling Alternative Masculinities: Representations Masculinitiens in Indonesian Men's Lifestyle Magazines, PhD Thesis, The University of Western Australia

Hall, S. (1989). Cultural Identity and Cinematic Representation. Framework. London, n. 36, p. 68-82

Hall, S. (1997). The spectacle of the "Other." Sage. In Hall, S.; Evans, J.; Nixon, S. (Orgs.). Representation: cultural representations and signifying practices. London: Sage, 1997. p. 225-279.

Kapolri Minta Jajarannya Berpikir Out of The Box. (2017, 9 Januari). Okenews. Diakses pada tanggal 9 Agustus 2020 dari: https:// nasional.okezone.com/ read/2017/01/09/337/1587121/kapolri-mintajajarannya-berpikir-out-of-the-box

Kachtan, D. G. (2016) “Deconstructing the Military's Hegemonic Masculinity: An Intersectional Observation of the Combat Soldier", Res Militaris, ERGOMAS issue no. 2, Women in the Military (Part Two).

Kapolda Sultra: Jaga Citra Polwan. (2020, 1 September). Antaranews. Diakses pada tanggal 15 Agustus 2020 dari: https:// www.antaranews.com/berita/1700026/kapolda- 
sultra-jaga-citra-polwan

Kartika D. (2016). "Representasi Citra Polri Dalam Foto Satire Di Situs 9gag”. Journal Unair, 3(2), pp. 83-91

Kitley, P. (1999). Pancasila in The Minor Key: TVRI's Si Unyil Models The Child. Indonesia, 68, 129152

Larasati, C. E. (2014). Representasi Identitas Etnis Papua Dalam Film Lost in Papua. Jurnal Commonline Departemen Komunikasi, 3(3), 488 $-497$

Lokataru Foundation. (2019). Catatan Peringatan Ulang Tahun Bhayangkara: Aparat Kepolisian (telah) 'Selalu Benar'. Jakarta: Policy Paper Lokataru.

Menjadi Pahlawan ala Police Movie Festival. (2020, 13 Juli). Remotivi. Diakses pada tanggal 1 September 2020 dari: https:// www.remotivi.or.id/video-detail/96

Nincic, M., and Ramos, J. M. (2009). The Dynamics of Patriotism: Survey and Experimental Evidence, Paper prepared for presentation at the annual meeting of the American Political Science Association, Toronto

Paramadhita, I. (2007). Contesting Indonesian Nationalism and Masculinity on Cinema, Journal of Asian Cinema, 18(2), pp.41-61

Parker, C., S. (2010). Symbolic versus Blind Patriotism: Distinction without Difference?, Political Research Quarterly, 63(1), pp. 97-114

Pautz, M. C. (2016). Cops on film: Hollywood's depiction of law enforcement in popular films, 19842014. PS - Political Science and Politics, 49(2), 250-258. https://doi.org/10.1017/ S1049096516000159

Polisi Akui Polisi Perempuan Haruslah Good Looking. (2018, 14 November). Tempo.co. Diakses pada tanggal 4 Agustus 2020 dari: https:// www.tempo.co/abc/3031/polri-akui-polisiperempuan-haruslah-good-looking

Program Polisi Sahabat Anak diintensifkan. (2020, 23 Januari). Antara Jateng. Diakses pada tanggal 4
Agustus $2020 \quad$ dari: https://

jateng.antaranews.com/ekonomi

Prysthon, A. (2016). Stuart Hall, Film Studies and The Cinema. Matrizes, 10(3), 77-88.

Pye, L. W. dan Pye, M. W. (1985). Asian Power and Politics: Cultural Dimensions of Authority, New Haven: Yale University Press

Reiner, R. (2010). The Politics of the Police. Oxford.

Rato Rasanae, D. L. M. (2013). Representasi Sosok Anak-Anak Pedalaman Papua dalam Film Denias, Senandung di Atas Awan, Skripsi Tesis Universitas Diponegoro.

Simpson, C. (1993). The Value of Patriotism, New York: Rosen-rosen

Stokes, J. (2013). How To Do Media and Cultural Studies. 2nd ed, London: Sage

Sutrisno, (2016). Sosiologi Kepolisian: Relasi Kuasa Polisi Dengan Organisasi Masyarakat Sipil Pasca Orde Baru, Jakarta: Pustaka Obor Indonesia

Survei "Kompas": Citra Polri Terus Meningkat. (2018, 4 Juli). Kompas.com. Diakses pada tangal 6 Agustus $2020 \quad$ dari: https:// nasional.kompas.com/ read/2018/07/04/16061011/survei-kompas-citra -polri-terus-meningkat

Tayipnapis, RG. (2019). Representasi Polri Dalam Pemberitaan Media Massa (Studi Analisis Wacana Kritis Pemberitaan Kasus Polri Pada Majalah Mingguan Tempo). Tidak dipublikasikan

Tentang Police Movie Festival. (2020). Police Movie Festival. Diakses pada tanggal 16 Agustus 2020 dari: https://policemoviefestival.com/about/

Thoha, A. M. (2005). Tren Pluralisme Agama: Tinjauan Kritis, Jakarta: Gema Insani

Thwaites, T., Davis, L., and Mules, W. (1994). Tools for Cultural Studies: An Introduction. South Melbourne: Macmillan Education

Tuai Kritik, Polri Jelaskan Anggaran Promosi Medsos 
Rp. 2,7 M. (2020, 27 Februari). CNN Indonesia.

Diakses pada tanggal 28 Agustus 2020 dari:

https://www.cnnindonesia.com/

nasional/20200227095418-12-478628/tuai-

kritik-polri-jelaskan-anggaran-promosi-medsosrp27-m

Wibawa, I. G. A. K. S. (2008). The Representation of Children in Garin Nugroho's Films, MA Thesis, Curtin University of Technology

Yumantle, C. (2015). Pluralism. Dalam M. T. Gibbons (ed), The Encyclopedia of Political Thought, New Jersey: John Wiley \& Sons, Ltd., 2724-274 